University of Warwick institutional repository: http://go.warwick.ac.uk/wrap

This paper is made available online in accordance with publisher policies. Please scroll down to view the document itself. Please refer to the repository record for this item and our policy information available from the repository home page for further information.

To see the final version of this paper please visit the publisher's website. Access to the published version may require a subscription.

Author(s): Chan, Winnie M. F. and Simester, A.P..

Article Title: Four functions of mens rea

Year of publication: 2011

Link to published article : http://dx.doi.org/10.1017/S0008197311000547

Publisher statement: (C) Cambridge Law Journal and Cambridge University Press. Chan, W. M. F. and Simester, A. P. (2011). Four functions of mens rea. The Cambridge Law Journal, 70(2), pp. 381 396. 


\title{
FOUR FUNCTIONS OF MENS REA
}

\author{
WinNie Chan AND A.P. Simester*
}

Everyone agrees that mens rea is relevant to fault. The maxim actus non fit reus nisi mens sit rea has been around for centuries. ${ }^{1}$ According to foundational principles of the criminal law, it is normally not enough to support a conviction that $\mathrm{D}$ perpetrates the actus reus. Neither should it be. Causing harm to another person may be unfortunate, but the moral turpitude associated with a criminal conviction requires some element of fault. And to show that, we need mens rea. The House of Lords recognized this candidly in Sweet v. Parsley, when holding that mens rea is a presumed element of all criminal offences: ${ }^{2}$

there has for centuries been a presumption that Parliament did not intend to make criminals of persons who were in no way blameworthy in what they did. This means that, whenever a section is silent as to mens rea there is a presumption that, in order to give effect to the will of Parliament, we must read in words appropriate to require mens rea.

In practice, that presumption is often rebutted, even for some every serious crimes. ${ }^{3}$ Yet the very existence of the mens rea presumption reflects an underlying idea that, unless the harm is caused advertently, or at least negligently, the attentions of the criminal law are inappropriate.

Some common law writers, however, adopt a more comprehensive analysis. They characterize mens rea as the fault element, suggesting not only that mens rea helps to establish culpability but, much more strongly, that this is its essential function. This approach reflects the understandable thought that the purpose of mens rea elements is to establish that the defendant has a "guilty mind". It is, after all, mens rea: the translation to "culpability element" might seem no more than a

\footnotetext{
* Respectively, Lecturer in Law, University of Warwick; Professor of Law, National University of Singapore and Fellow, Wolfson College, University of Cambridge.

${ }^{1}$ See, e.g., Coke, Third Institute (1641) 6, 107; Fowler v. Padget 7 Term Rep. 514 (Lord Kenyon). Cf. Bracton, De Legibus et Consuetudinibus Angliae, 101b; also C.S. Kenny, Outlines of Criminal Law, 2nd ed., (Cambridge University Press, 1904) 39: "no external conduct, however serious or even fatal its consequences may have been, is ever punished unless it is produced by some form of mens rea."

2 [1970] A.C. 132, 148 (Lord Reid); see also at 153 (Lord Morris) and 162-3 (Lord Diplock). Cf. Bv. DPP [2000] 2 A.C. 428.

${ }^{3}$ Notably in under-age sexual offences: now the Sexual Offences Act 2003, ss. 5-8.

${ }^{4}$ Nothing turns here on the vexed but semantic question whether negligence is a form of "mens rea" or mental state, in as much as it may be a fault element without involving any particular state of mind. For convenience of expression, we assume that it is.
} 
step in the flight from literacy, the abandonment of yet another Latin affectation.

That thought should be resisted. Certainly, mens rea in some form is a necessary component of culpability findings. But it is not sufficient. Guilt rests on other elements too. Showing mens rea requires only that the prosecutor establish that the defendant had, at the time of doing the actus reus, the specified mental state toward that actus reus which is required for the crime. In itself, this is incomplete. Proof of mens rea does not establish that the defendant did anything that was culpably wrong. In particular, she may avail herself of a variety of justifications or excuses, thereby defraying the attribution of fault despite the presence of mens rea. ${ }^{5}$ Even a finding of insanity is compatible with that conclusion; ${ }^{6}$ all the more so for the rationale-based defences, such as self-defence and duress, where the defendant concedes mens rea but goes on to offer further and exculpating reasons why she chose to do the actus reus. Mens rea is not the whole of the fault story.

Indeed, liability for a mens rea offence is quite often incurred despite the absence of moral fault. In the troubling case of Kingston, ${ }^{7}$ D was invited to T's flat, apparently to discuss some business matters. Once there, he was given coffee which T had laced with disinhibiting drugs. ${ }^{8}$ $\mathrm{D}$ was then led to a bedroom where a fifteen-year-old boy, also drugged, lay unconscious on the bed. D, who had no previous record of such behaviour, performed non-penetrative sexual acts on the boy. When charged with indecent assault, D did not allege that he was unaware of his conduct. At most, he could claim only that, except for being drugged unawares, he would not have acted as he did. Even so, the Court of Appeal quashed D's conviction, characterising D's intent as not being a "criminal" intent; a decision that linked the finding of mens rea directly to considerations of fault.

The House of Lords restored D's conviction, and ruled that the absence of blame did not entail the absence of mens rea. Giving the judgment of the House, Lord Mustill asserted that mens rea is a technical matter, which requires only that the mental element specified in the definition of the crime is present. Given that the respondent had mens rea, the circumstances of the offence warranted mitigation.

${ }^{5}$ This holds especially for purely cognitive forms of mens rea such as intention or knowledge. On the other hand, the presence of a justification may block findings of certain partially evaluative mens rea elements, such as recklessness or dishonesty.

${ }^{6}$ Pace the Divisional Court in D.P.P. v. H [1997] 1 W.L.R. 1406, which ruled that the insanity defence has no application to strict liability offences, on the basis that the defence operates to negate D's mens rea. But a successful plea of insanity is compatible with the presence of mens rea, at least where D's condition is such that he lacked knowledge that his act was wrong: M'Naghten (1843) 10 C. \& F. 200, 8 E.R. 718.

7 [1995] 2 A.C. 355 (HL); [1994] Q.B. 81 (CA). Cf. Hinklin (1868) L.R. 3 Q.B. 360, 370-2; Yip ChiuCheung [1995] 1 A.C. 111.

${ }^{8}$ It appears from the trial evidence that the defendant was slipped three different kinds of drug, which were likely to affect judgment, consciousness, and memory. 
Whereas no recognised defence was available, however, a conviction would follow.

One may question Kingston's conviction, yet the conclusion that he had mens rea was surely right. If he was not culpable, then in principle he should not be convicted. ${ }^{9}$ But that is a matter for the defences. Perhaps we should craft an "involuntary disinhibition" excuse for rare cases such as these, although their Lordships saw that framing such an excuse would not be easy. ${ }^{10}$ However, we should not conceal the true difficulty by pretending that someone who does things for good reasons then lacks "a criminal intention". A person who shoots another in self-defence intends to do so. Neither should we accept the analysis in Williams (Gladstone) ${ }^{11}$ and Beckford v. $R^{12}$ that such a person lacks the intent to act "unlawfully" ${ }^{13}$ Rather, he is not culpable: and that is rightly reflected through a supervening defence. ${ }^{14}$

Mens rea is not sufficient, then, to establish fault. Moreover, in one sense it is not even necessary. Certainly, some element of mens rea will be required before a defendant can properly be treated as blameworthy for the consequences of his actions. Presaging the famous decision in Sweet v. Parsley, ${ }^{15}$ Lord Russell claimed in Williamson v. Norris that " $[\mathrm{t}]$ he general rule of English law is, that no crime can be committed unless there is mens rea." So should it be. But it does not follow that every actus reus element should be accompanied by a corresponding mens rea requirement. Sometimes, constructive liability may be justified. Hence, in the offence of dangerous driving causing death, ${ }^{17}$ there is no need to show mens rea in respect of the occurrence of death. Death is a strict liability element: none the less, culpability lies in respect of the entire offence. One who causes death by driving dangerously is

\footnotetext{
9 Pace Lord Mustill in Kingston itself, at 365: "In respect of some offences the mind of the defendant, and still less his moral judgment, may not be engaged at all. In others, although a mental activity must be the motive power for the prohibited act or omission the activity may be of such a kind or degree that society at large would not criticise the defendant's conduct severely or even criticise it at all. Such cases are not uncommon. Yet to assume that contemporary moral judgments affect the criminality of the act, as distinct from the punishment appropriate to the crime once proved, is to be misled by the expression 'mens rea', the ambiguity of which has been the subject of complaint for more than a century. Certainly, the 'mens' of the defendant must usually be involved in the offence; but the epithet 'rea' refers to the criminality of the act in which the mind is engaged, not to its moral character." We can accept Lord Mustill's analysis that the absence of blame should not entail the absence of mens rea. Read as an assertion that the absence of blame should not entail the absence of a conviction, however, we should demur. For insightful discussion, see G. Sullivan, "Making Excuses" in A.P. Simester and A.T.H. Smith (eds.), Harm and Culpability (Oxford 1996), 131.

${ }^{10}$ Kingston, at 375-7.

11 (1983) [1987] 3 All E.R.411 (CA).

${ }^{12}[1988]$ 1 A.C. $130(\mathrm{PC})$.

13 For criticism of that approach, see A.P. Simester, "Mistakes in Defence" (1992) 12 O.J.L.S. 295.

${ }^{14}$ Similarly, in the context of medical necessity, see the argument by A. Ashworth, "Criminal Liability in a Medical Context: the Treatment of Good Intentions" in A.P. Simester and A.T.H. Smith (eds.), Harm and Culpability, 173.

15 Above, text at n. 2.

${ }_{17}^{16}$ [1899] 1 Q.B. 7, 14. (Unfortunately, as we noted earlier, it is a rule plagued by exceptions.)

${ }^{17}$ Contrary to s. 1 of the Road Traffic Act 1988.
} 
normally culpable in respect of that death - because it is precisely such risks that make it wrong to drive dangerously in the first place. ${ }^{18}$

\section{BEYOND CULPABILITY}

So we may quibble about the close - too close - identification that is sometimes made between mens rea and culpability. Admittedly, mens rea is indispensable to culpability, in that we need more than a bare actus reus to conclude that a defendant deserves the official sanctions of the criminal law. Yet the contribution made by mens rea is not sufficient either; and its role in establishing fault is not a simple one.

More importantly, however, we should question the conventional association between mens rea and culpability at a deeper level. Mens rea is relevant to culpability, yes. But it serves other purposes too, purposes that are quite distinct and just as important. The existence of these other functions is too often overlooked, and is liable to be concealed by the depiction of mens rea simply as a "fault" element.

Broadly speaking, mens rea serves two main classes of function, and within that grouping it serves at least four particular functions. First, it helps to establish the moral innocence or guilt of the defendant's conduct (and as such, affects sentencing as well as conviction). We have noted already that it does so partly by contributing to findings of culpability. Additionally, as we see in the next section, sometimes mens rea constitutes the morally wrongful character of D's behaviour in a more fundamental way, by identifying what kind of action $\mathrm{D}$ is performing. In these cases, the finding of mens rea is integral to the wrong for which $\mathrm{D}$ is being held responsible.

The other functions concern liberty. Mens rea has important roles to play in articulating, and notifying, the limits of citizens' freedom. More specifically, one purpose discharged by mens rea is to secure fair warning to defendants, ensuring they have sufficient advance notice that, by their conduct, they risk violating the criminal law. Secondly, mens rea plays a key mediating role in criminalisation, being part of the trade-off between the protection of potential victims and the preservation of liberties for potential defendants.

These further roles often demand more stringent mens rea standards for liability than is needed to establish culpability. They help to explain why negligence, and sometimes even recklessness, is excluded in certain contexts of the criminal law, notwithstanding that one so acting might be culpable. In what follows, we discuss each role in turn.

\footnotetext{
${ }^{18}$ See further A.P. Simester, J.R. Spencer, G.R. Sullivan, and G.J. Virgo Simester and Sullivan's Criminal Law: Theory and Doctrine, 4th ed. (Oxford, 2010) § 6.5 (hereafter Simester and Sullivan).
} 


\section{ESTABLISHING THE WRONG}

The second function sometimes performed by mens rea, then, is to establish the morally wrongful nature of a defendant's behaviour. As a general proposition, criminal conduct must be wrongful. It must be the kind of behaviour that a person ought not to do, ${ }^{19}$ for which blame and punishment are potentially apt. We don't blame people for doing good things. We blame them only for doing things that are morally wrong. Notice that this is not just a point about culpability. There is a general objection to punishing the blameless in criminal law, but conclusions of blamelessness can be attributable to different sources. One may be blameless because, although one's conduct was wrongful, one was not culpable in respect of that conduct - as when one lacked mens rea, or had an appropriate excuse. But one may also be blameless because one's conduct was not wrongful in the first place. Thus the primary step is to establish whether the conduct is suitable for blame at all. This primary step not only affects conclusions about the defendant's moral position; it also shapes the justificatory rights of others to assist or resist him.

But what makes conduct wrongful? Let's start by thinking about the actus reus in isolation. Often the answer is straightforward. What makes D's behaviour problematic, and a candidate for potential blaming judgments, is some observable harm that it causes. If $\mathrm{D}$ breaks V's arm, or vandalises his property, the conduct is undesirable - the actus is reus - just in virtue of its external elements, and independently of D's mens rea. In these kinds of cases, the conduct is the very source of the wrong. Correspondingly, the criminal law's interest in preventing such conduct arises out of the harmful nature of the actus itself. These are the classic types of cases likely to influence us toward thinking of mens rea as a fault element. The actus reus establishes the harm; and we can move directly to the second stage, of establishing culpability.

On other occasions, however, the actus is not inherently reus. The external elements of D's conduct may not by themselves disclose anything wrongful or undesirable. Suppose that D stalks toward V with fist drawn back. What is the moral character of D's conduct? It depends. Perhaps D intends to strike V. Or perhaps D is a criminal law professor, acting out a scenario in order to demonstrate the moral ambiguity of such cases to his students. Whether D's conduct is a wrong of attempted assault depends on D's intentions. It is only if he means to strike that D's otherwise lawful conduct becomes a wrong. The same is true of theft. Picking up a glass of beer from the bar counter is not the stuff of theft, although it is the actus reus of theft.

${ }^{19}$ Cf. Simester and Sullivan ch. 1. 
It lacks the nature of theft, unless and until it is done dishonestly with intent to deprive. In cases like these, D's mental state is integral to the moral character of his action. Without it, there is no reason to think of his conduct as wrong, as the kind of morally problematic conduct that warrants preventive measures by the state.

Helping to constitute the wrong is a standard role for mens rea. Consider, for example, the former English law of indecent assault. In Court, ${ }^{20} \mathrm{D}$ placed a 12 year old girl, fully clothed, across his knees and beat her on the buttocks. The House of Lords ruled that such conduct, if a disciplinary measure, was a mere assault; but if done for sexual gratification, the assault was indecent. The decision allows that some actions are not, by their external elements, inherently wrongful, but are capable of being made wrongful when done for certain kinds of reasons. Court's ulterior motivation was not a fault constituent. Rather, it made his conduct the kind of wrong it was.

There are many examples like Court to illustrate that the character of an action cannot always be determined by reference to its external, actus reus features alone. Glanville Williams put the point more generally: 'the act constituting a crime may in some circumstances be objectively innocent, and take its criminal colouring entirely from the intent with which it is done." 21 Where that is so, the law may have no regulatory interest in D's conduct unless it is done for certain reasons. For these varieties of crime, mens rea does not operate simply to establish fault (although it also does that): because, in itself, the actus reus does not specify a wrong. It is only when accompanied by mens rea that there is an action meriting the attention of the criminal law. As such, the mens rea requirement does far more than simply establish a connection between the eventual harm and D's culpability.

Our modern criminal law contains some very important classes of offences that involve mens-rea-dependent wrongs. ${ }^{22}$ These include most economic wrongs, such as exploitation and predatory behaviour; and indeed blackmail, where the distinction between a threat and a warning depends on the defendant's motivation. ${ }^{23}$ To some extent the dependence of economic wrongs on mens rea is an inevitable feature of marketplace transactions, where the actions of an economic actor are always likely to affect the interests of others. D may know that, by pricing her goods lower, she will take business away from $\mathrm{V}$, and perhaps even force $\mathrm{V}$ out of business. Yet $\mathrm{D}$ does no wrong unless she prices her goods accordingly in order to drive $\mathrm{V}$ out of business.

\footnotetext{
${ }^{20}$ [1989] A.C. 28.

${ }^{21}$ Criminal Law: The General Part, 2nd ed. (London 1961), p. 22.

${ }^{22}$ Especially in ulterior intent crimes. See J. Horder, "Crimes of Ulterior Intent" in A.P. Simester and A.T.H. Smith (eds.), Harm and Culpability, 153.

${ }^{23}$ Cf. G. Lamond, "Coercion, Threats, and the Puzzle of Blackmail" in Simester and Smith, ibid., 215.
} 
Here, the distinction between a side-effect of economic activity and an intended effect is central to our assessment of the wrongfulness of D's conduct. V's economic interests are by their nature exposed to the adverse effects of others' economic activity: there is no general duty to avoid injury to economic interests, and the mere fact that those interests are harmed cannot establish that D's act wrongs the victim. Hence it is only the intention with which $\mathrm{D}$ acts that makes her conduct properly described as a (wrongful) attack on V. In a broadly free market, persons are left alone to pursue their own interests. In so doing, they wrong no-one even if their self-advancing conduct has deleterious side-effects for others. Those side-effects are a natural feature of competitive interaction. However, where they are deliberately sought, D is no longer pursuing her own interests but, instead, attacking the interests of others. That is morally wrongful; and it is wrongful even if she attacks those interests merely in order to advance her own position (a characteristic of wrongs such as dumping).

Another significant class of intention-dependent wrongs comprises pre-emptive crimes. Pre-emptive crimes seek to prohibit conduct that is not in itself harmful, but which becomes problematic when perpetrated for nefarious ends. There is nothing wrong with buying fertiliser; but if done with intent to make a bomb, an offence is committed against section 5 of the Terrorism Act 2006. ${ }^{24}$ Pre-emptive offences often involve a trade-off between actus reus and mens rea. Sometimes, it will be better to criminalise a more specific actus reus, e.g. possession of an automatic firearm. The more precisely defined offence offers better, more detailed guidance to citizens about their freedoms and obligations, letting them know where the law stands by marking out what counts as wrongful conduct clearly in advance. But as the inchoate law of attempts itself demonstrates, sometimes this precision about the actus reus is not available. In such cases, we rely on the defendant's intention to help mark out those inchoate acts that are wrongs, and which constitute a criminal attempt, or a crime against the Terrorism Act 2006, or some other preparatory offence. Moreover such intentionrich offences, despite their intangible actus reus, will frequently supply greater accuracy when labelling D's criminality, because they more clearly identity the moral character of D's behaviour. ${ }^{25}$ A conviction of some (hypothetical) offence of buying controlled fertilizer may not adequately describe D's wrongdoing in a case where D's intention was to manufacture a bomb. In such cases, doctrines of mens rea enable the

\footnotetext{
${ }^{24}$ Section 5 creates an offence of preparation of terrorist acts. According to subsection (1), "a person commits an offence if, with the intention of (a) committing acts of terrorism, or (b) assisting another to commit such acts, he engages in any conduct in preparation for giving effect to his intention."

${ }^{25}$ Cf. A. Ashworth, Principles of Criminal Law, 6th ed. (Oxford 2009) § 3.6(s); Simester and Sullivan $\S$ 2.4 ("fair labelling").
} 
law to establish flexible prohibitions while controlling the risk of attaching liability to morally innocent conduct.

\section{FAIR WARNING}

Let us turn now to the second class of mens rea functions, which concerns the protection of citizens from state intervention. One form of contribution is through what scholars often call the "fair warning" principle. ${ }^{26}$ This is not quite the same as the overlapping principle that the liability of citizens should be ascertained by determinate legal rules, and we need to begin by getting that distinction clear. Both involve rule of law values. The latter, which is sometimes known as the principle of legality, requires that no-one should be convicted of any offence unless a law exists that designates her conduct a crime: nullum crimen sine lege, no crime without law. It also requires that the law should be prospective, not retrospective. Nowadays, it is a constitutional matter: the common law contains a presumption against retrospective crimes, buttressed by Article 7 of the ECHR, which plainly interdicts retroactive criminal laws. The law, especially the criminal law, should be fixed and definite, not alterable. The potential for criminal liability of a would-be actor should exist before she acts, not originate in the subsequent discretion of others.

The legality principle requires that liability should be determined by the rule of law, and not the rule of officials. By contrast, concern for fair warning brings out a slightly different dimension of the rule of law: that its rules should offer advance guidance to the persons who are subject to them. An unpublished law may be constitutionally valid, for instance, but it is defective as part of a system of rules designed to guide society's behaviour - like the doomsday device in Dr Strangelove, it fails as a deterrent. The distinction is helpfully brought out by Lord Bingham in Rimmington and Goldstein ${ }^{27}$

There are two guiding principles: no one should be punished under a law unless it is sufficiently clear and certain to enable him to know what conduct is forbidden before he does it; and no one should be punished for any act which was not clearly and ascertainably punishable when the act was done.

Bingham's second principle is the basic constitutional one: that if something is not illegal, no liability can follow even if it ought to be illegal, and indeed even if most people thought it was. ${ }^{28}$ His first

\footnotetext{
${ }^{26}$ See, e.g., Simester and Sullivan $\S 2.3$ and citations there.

27 [2005] UKHL 63, [2006] 1 A.C. 459, [33].

28 It is this second, constitutional principle that is especially worrying about the decision in $C$ [2004] EWCA Crim 392, [2004] 1 W.L.R. 2098, where C appealed his conviction in 2002 of raping his wife in 1970. Relying on the House of Lords' decision in $R$. v. $R$ [1992] 1 A.C. 599 (below in the text), the Court of Appeal simply pronounced (at [22]) that "the stark fact is that R was convicted... The
} 
principle, on the other hand, concerns predictability and fair warning. Individuals need to be able to predict the legal implications of their actions in advance, so that they have fair warning that their contemplated actions will risk incurring a criminal sanction; so that they know where they stand and can properly decide what to do in light of the law's guidance. With secure, reliable law, citizens are enabled to steer clear of criminal liability by choice, to navigate their way through life without unexpected legal consequences befalling them. Absent such law, the ability to plan one's life is undermined.

There is a growing tendency to constitutionalise this principle too. Fair warning ordinarily requires not only that criminal laws exist prospectively, but also that they be stated clearly and in a reasonably precise fashion. Extending the Article 7 jurisprudence, the European Court has emphasised the aim that "the individual can know from the wording of the relevant provision and, if need be, with the assistance of the courts' interpretation of it, what acts and omissions will make him liable." ${ }^{29}$ That ambition seems hard to contest. None the less, caution is appropriate here. The goal of fair warning is not to ensure textual certainty for its own sake. What really counts is whether D can anticipate liability in the case at hand - whether criminal liability comes as a surprise, as something contrary to ex ante expectations..$^{30}$ A focus on predictable liability rather than legislative clarity leaves space for what Andrew Ashworth calls a "Thin Ice" principle:"31

A rounded view of the doctrine of criminal law must, however, look further than the cluster of three legality principles. If one of the aims of the criminal law is to convict those who culpably cause harm, this constitutes a policy goal which should form part of the doctrine of criminal law and which may properly enter into decisions on interpretation. The claim here is not that criminal laws should be extended retrospectively to citizens' conduct, but rather that people who knowingly "sail close to the wind" should not be surprised if the law is interpreted so as to include their conduct. This may be termed the "thin ice" principle, after the dictum of Lord Morris that "those who skate on thin ice can hardly expect to find a sign which will denote the precise spot where he [sic] will fall in." ${ }^{32}$ Surely this argument might properly militate against a restrictive construction: the essence of the non-retroactivity principle is that the courts should not frustrate justified expectations,

decision [by their Lordships] applied to events that had already taken place, as well as those in the future."

29 Kokkinakas v. Greece (1993) 17 E.H.R.R. 397, 423. Cf. G v. Federal Republic of Germany 60 D.R. 252, 262 (1989); Misra and Srivastava [2004] EWCA Crim 2375, [29]-[34].

${ }^{30}$ Cf. John Gardner's introduction to H.L.A. Hart's Punishment and Responsibility 2nd ed.(Oxford 2008) xxxvi: "the law must be such that those subject to it can reliably be guided by it, either to avoid violating it or to build the legal consequences of having violated it into their thinking about what future actions may be open to them." (Emphasis added.)

31 "Interpreting Criminal Statutes: A Crisis of Legality?" (1991) 107 L.Q.R. 419, 443.

${ }^{32}$ Knuller v. D.P.P. [1973] A.C. 435, 463. 
and these should not exist in controversial or manifestly doubtful cases.

To be sure, obscure or discretionary (or retroactive) laws are likely to be insufficiently predictable, likely to offer inadequate ex ante guidance to citizens. But, if the objection is one of fair warning rather than the constitutional one of retroactive criminalisation, disappointing the ex ante expectations of a defendant may carry no weight when those expectations are unjustified. And expectations may be unjustified because of the kind of conduct the defendant contemplates, not just because of clearly-drafted prohibitions. One illustration of this is the well-known decision in $R$. v. $R,{ }^{33}$ where the House of Lords rejected spousal immunity in the common law crime of rape, thereby upholding the defendant's conviction of attempting to rape his wife. The decision is defensible on a thin-ice basis: when interpreting the current law of rape, R's anticipation of a legal immunity generated no reason for the courts to find one. It should have made no difference had $\mathrm{R}$ obtained an opinion from a lawyer, immediately prior to making his wife submit to intercourse, that in legal terms he would not be committing rape. His conduct was profoundly wrong, the very wrong of rape. This is not to say that courts may invent law retroactively in order to catch husbands who rape their wives. (That would violate the constraint of legality. ${ }^{34}$ ) But it is to say that, in considering what the current law is, the fact that the defendant thought it was different does not count for much in circumstances like these..$^{35}$ The goal of fair warning is met here.

Understood in this wider sense, of liability's being anticipatable and not surprising, fair warning is also supported by mens rea requirements. H.L.A. Hart saw this clearly. ${ }^{36}$ Indeed, for Hart, warning rather than fault is the basic function of mens rea. By proving intention or recklessness, the prosecution establishes that $\mathrm{D}$ chose to perpetrate the actus reus; this, in turn, serves to ensure that D had (and rejected) the opportunity to avoid wrongdoing, and so to evade the attentions of the criminal law. ${ }^{37}$ Perhaps Hart exaggerated. Certainly, he underestimated the distinctive importance of fault in the criminal law. ${ }^{38}$ But he was right to observe that, by ensuring that the defendant has notice of his actions, mens rea requirements foster the rule of law.

\footnotetext{
${ }^{33}$ [1992] 1 A.C. 599.

${ }^{34}$ Which is effectively what happened in $C$ (above, n. 28)

${ }^{35} \mathrm{Cf}$. Simester and Sullivan $\$ 2.3$.

${ }^{36}$ See, e.g., H.L.A. Hart, "Punishment and the Elimination of Responsibility" in Punishment and Responsibility (Oxford 1968) 158, at pp. 181-2.

${ }^{37}$ Subject, of course, to the possibility of defences: cf. H.L.A. Hart, "Legal Responsibility and Excuses" in Punishment and Responsibility, ibid.

${ }^{38}$ A point made by J. Gardner, "Wrongs and Faults" in A.P. Simester (ed.), Appraising Strict Liability (Oxford 2005) 51, at p. 71.
} 
The fair warning role of mens rea is especially important in the contexts of result crimes and omissions liability. Crimes of these sorts often involve no particular form of conduct, no conduct of a kind that might put the defendant on notice that $-10 !-a$ conviction is at hand. Result crimes such as manslaughter, or criminal damage, require only that death, damage, etc., be caused by any act. If I walk into a new building and switch on the light, I may have no idea that, because of some fault in the wiring system, an explosion will result, perhaps causing fatalities. And there is nothing distinctive about switching on a light to alert me to the potential for danger.

The same holds for omission-based liability, which is by definition activity-unspecific. We do not complain of what the defendant does, but of what he does not. Yet there are so many ways in which one can fail to rescue another person, so many things one may be doing instead. Perhaps I am talking on the "phone, or walking to work, or eating my lunch, and romancing a new friend, or writing an article.... Any of these things may be engaging my attention while, at the same time, I am failing to rescue the victim. Easy to see, then, how liability might come as a shock.

Considerations of fair warning supply one ground why we tend to restrict omissions liability to specialist actors, such as parents and doctors. Part of the reason for our willingness to impose positive legal duties on such actors is that we can expect them, in virtue of their roles, to be on notice of the need to act; to look out for the interests of those to whom they owe such duties. Even then, positive obligations have the potential to surprise. There are so many things that a parent has to do each day, some involving her children and many not, that we cannot reasonably expect any parent constantly to be alert to the possibility that something may be amiss, constantly to be thinking about her charges to the exclusion of the rest of her life.

Mens rea requirements address this problem by helping to make sure that the result, or the omission, is not out of the blue. For those types of crime in particular, there is especial reason why stigmatic criminal liability should normally be confined to reckless or intentional wrongdoing. Otherwise, liability for inadvertent harms can make it too difficult for citizens, even citizens owing specific legal duties, to pursue their own lives without fear of unexpected criminal charges. If whatever activity they are engaged in does not itself give them notice of disaster, then we must rely on mens rea to ensure they have it.

John Gardner, however, would go even further. Advancing what he describes as "the mens rea principle", he argues that "criminal wrongs should be such that one does not commit them unless one intends or is aware of at least one wrong-making feature of what one is about to do, such that (assuming one knows the law) one is also alerted to the fact 
that what one is about to do will be of interest to the criminal law." 39 Thus Gardner requires awareness rather than notice. The rationale for his principle is also rooted in fair warning arguments, along the lines advanced originally by Hart: ${ }^{40}$

According to the ideal known as the rule of law, those of us about to commit a criminal wrong should be put on stark notice that that is what we are about to do. The criminal law should not ambush us unexpectedly. Of course, to avoid unexpected ambushes we all need to know what the law requires of us. For that reason, criminal laws should be clear, open, consistent, stable, and prospective. They should also forbid specific actions (not courses of action, activities, ways of life, etc.). Even all this, however, is not enough to ensure that those of us about to violate the criminal law are put on stark notice that we are about to violate it. For we may know the law and yet have no grasp that what we are about to do might constitute a violation of it. That is because often we have no idea which actions we are about to perform. I make a light-hearted remark and (surprise!) I offend one of my guests. I turn on my oven and (surprise!) I blow all the fuses. The mens rea principle is the principle according to which such actions - the self-surprising ones - should not be criminal wrongs.

There is much to admire in this analysis, including its rule-of-law commitment to protect subject-citizens from oppressive and unexpected use against them of the state's power. But Gardner's conclusion now strikes us as being too strong. ${ }^{41}$ This is for two reasons. First, to the extent that the rule of law enjoins unpredictable interference by the State, liability for negligence is reasonably predictable. Moreover, unless negligence liability be no deterrent, the argument prima facie deprives victims of protection from similarly unlooked-for intrusions by other citizens. The demand that notice be "stark" seems unduly weighted in favour of defendants. At least where the interest at stake is sufficiently important, as in manslaughter, a mens rea standard of gross negligence may be defensible. ${ }^{42}$

Secondly, and perhaps more importantly, Gardner's requirement that a criminal wrongdoer must intend or be aware of at least one wrong-making feature of the action neglects the gateway role of some activity-specific prohibitions. Perhaps the best example of this is rape. There is nothing wrong, or wrong-making, about sexual intercourse. But one reason why it is acceptable to criminalise negligence with respect to non-consensual sex, as many jurisdictions have, is that matters of consent are so closely bound up with the very nature of sexual

\footnotetext{
${ }^{39}$ Ibid., p. 70.

${ }^{40}$ Ibid., pp. 69-70.

${ }^{41}$ Although his editor was persuaded at the time.

42 This claim assumes that an adequately formulated (gross) negligence standard can take account of intellectual limitations of the defendant. For related discussion, see Simester and Sullivan $\S 5.5(\mathrm{ii})$.
} 
intercourse that those engaging in sex are, implicitly, on notice that questions of consent are in play. The context is so intimate that alertness to the will of one's partner can be expected of every responsible actor, and a failure to exhibit such alertness is itself ground for condemnation. It isn't like carelessly tossing a stone aside, only (surprise!) to hear the sound of breaking glass. To make criminal damage an offence of negligence would be unfair because there is not always reason to inquire about the circumstances of one's conduct. Sometimes the unexpected happens. But sex is a specific activity, and not like behaviour that happens to cause property damage. It is distinctive in a manner that generates an immediate and obvious duty to consider whether one's partner consents.

Gardner's principle is absolute, but in our view fair warning constraints admit of a trade-off; one in which mens rea plays a part. Notice of impending criminal liability must be adequate rather than stark. Some activities are more obviously dangerous than others, some interests more in need of protection. The same holds for omission-based duties, some of which are more specific than others. The anaesthetist may be surprised to find that a tube is detached, ${ }^{43}$ just as the railway gatekeeper may be startled to discover the gate left open. ${ }^{44}$ Neither can complain, however, that these events were unlooked-for. In other cases, by contrast, it may only be the presence of mens rea, and in particular of intention or advertence, that guarantees sufficient warning of imminent liability.

\section{NEGOTIATING THE PARAMETERS OF CRIMINALISATION}

The fourth role of mens rea is the least familiar. It too concerns the relationship of citizens with the state. As well as helping to secure fair warning, the so-called "fault" requirements in offences can also play an important role in mediating the scope of the prohibitions themselves, especially for those offences where the mental element is not required to identify a wrong.

It is common, indeed too common, for criminal lawyers to think of the criminal law in ex post terms, where the defendant has already acted; and our task is to decide whether she satisfies the criteria of an offence, including all of its actus reus and mens rea components. At this ex post stage, the temptation is to focus on the particular defendant, the character and circumstances of her conduct, and on whether she deserves punishment for what she has done. Seen from that perspective, it is easy to conceive of the offence specification as setting the criteria of punishment. But, as our discussion of fair warning suggested, that

${ }^{43}$ Adomako [1994] UKHL 6, [1995] 1 A.C. 171.

${ }^{44}$ Pittwood (1902) 19 T.L.R. 37. 
conception is incomplete. The offence should exist even before $\mathrm{X}$ is done. This is because the primary role of an offence is, ex ante, to articulate a prohibition. Do not do $\mathrm{X}$ in future, the prohibition says, and it backs that up with a threat of punishment. ${ }^{45}$

This ex ante role is central to the operation of any offence as deterrent. It is the threat of punishment, not the punishment itself, that is meant to deter would-be wrongdoers. The question of punishment only arises, in a sense, once the prohibition has failed. So we should begin by considering offences from an ex ante, deterrent perspective: as measures of criminalisation. (And, when interpreting offences, we should be less tempted to respond to backward-looking considerations about the culpability of the particular defendant, and driven rather more by the forward-looking implications of a given interpretation for the scope of activity the offence prohibits.)

Seen from that perspective, our point here is that the content of the prohibition includes the mens rea specification, and that the nature of its mens rea requirement directly affects the deterrent scope of the proscription.

By way of example, let us start with a putative offence where the actus reus comprises sexual intercourse with a person under the age of 16 years. Consider, next, what this offence leaves us free to do. The answer depends on its mens rea requirement. If, to commit the offence, D must intend or know that her partner is aged under 16, then $\mathrm{D}$ is left with considerable freedom of action. She must refrain from sex only when she knows or purposes that her partner be underage.

Contrast a mens rea element of (subjective) recklessness. If recklessness suffices for a conviction, it follows that D must refrain from sex whenever she suspects that her partner may be underage. By contrast with the knowledge-based offence, the scope of the prohibition is become larger: the former version permits her to proceed despite realising $\mathrm{V}$ may be underage; the latter does not.

All the more so when, as currently under English law, the mens rea element is negligence. Now D is not at liberty to have sex unless she takes care to check V's age. We do not mean by this to suggest that a prohibition of negligent under-age sex is inappropriate. Our point is simply that it is broader, more intrusive, and that its wider scope needs to be justified. Broader still would be the extreme case of strict liability, in which case D could only be sure of avoiding liability by refraining from sex altogether. ${ }^{46}$

\footnotetext{
${ }^{45}$ For a fuller outline of the nature of criminalization, see A.P. Simester and A. von Hirsch, Crimes, Harms, and Wrongs: On the Principles of Criminalisation (Oxford 2011) ch. 1.

${ }^{46}$ Cf. Sexual Offences Act 2003, ss. 5-8 (offences against children under 13).
} 
Similar analysis applies to an actus reus such as causing damage to another's property. Current English law leaves people with the latitude to be careless but not the freedom deliberately to take risks. ${ }^{47}$ The difference may look like one of culpability; but it is also, and perhaps even primarily, a difference of liberty. When contemplating whether to prohibit conduct, one should not only consider the magnitude and seriousness of the harms involved. One should also consider the value of the conduct to be prohibited and the impact of its proscription upon the freedom of citizens. ${ }^{48}$ Mens rea elements can help to negotiate these considerations. They help to balance the invasiveness of a prohibition against the interests of those whom the law seeks to protect. Setting a more stringent mens rea requirement means that the prospect of liability will have less impact on the day-to-day lives of law-abiding individuals. Simply put, persons will be required to alter their behaviour on fewer occasions - e.g., only when they know, or suspect, or ought to know (as the case may be) about the risk. By pitching the standard of mens rea higher, we make it easier for citizens to comply with the law, and we reduce the range of activities they have to sacrifice in order to avoid the risk of a criminal conviction. ${ }^{49}$

The criminal law is designed to safeguard us from threats of harm. But criminal prohibitions are themselves threatening, in so far as they coercively restrict our freedom. Ordinary citizens must not only be shielded from the predations of others; they need also to be shielded from the state, which should not intrude upon their everyday, innocent activities. Quite apart from its other roles, the requirement of a mental element has an important function to play in keeping citizens outside the scope of criminal prohibitions. Mens rea, that is to say, protects freedom.

\section{CONCLUSION}

Conventionally, mens rea is thought of as a fault requirement. Helping to establish culpability on the part of the defendant is certainly one of its roles, and we have no wish to detract from the importance of that role. Our claim is that it has other roles too. Mens rea requirements can perform at least four different sorts of function in an offence, and those other effects need also to be considered when discussing what mens rea standard ought to be set for a given offence.

Indeed, it is those other functions, and not culpability, that supply the main explanations why negligence should be used so rarely in

${ }^{47}$ Criminal Damage Act 1971, s. 1.

${ }^{48}$ The classic study is J. Feinberg, Harm to Others (Oxford 1984); see also Simester and von Hirsch (note 45 above), ch. 3.

${ }^{49}$ For an argument along these lines in the context of complicity liability, see A.P. Simester, "The Mental Element in Complicity" (2006) 122 L.Q.R. 578, 591-2. 
serious offences. Despite claims by some writers to the contrary, ${ }^{50}$ it seems plausible to conclude that inadvertent negligence can be culpable. ${ }^{51}$ It isn't a lack of fault that prevents negligence from being used more commonly. Rather, in some crimes there is no place for negligence liability because D's intention or awareness contributes to making the conduct a wrong. And more generally, limiting the use of negligence helps to constrain state power, both by reducing the risk of unexpected liability and by restricting the deterrent scope of the law's prohibitions. To appreciate this last explanation, though, we have to stop focusing on the criminal law as a punishing institution, and become more willing to think about it from a forward-looking perspective, as a body of ex ante proscriptions.

Some of the propositions advanced in this essay are familiar. They should be more familiar than they are. The purpose of this essay is, primarily, to draw them together. Seen alongside, we hope the points made here are enough to demonstrate that mens rea is not, uniquely or even predominantly, about fault. Actus non fit reus nisi mens sit rea may be a beginning. But it is far from the end..$^{52}$

${ }^{50}$ C. Finkelstein, "Responsibility for Unintended Consequences" (2005) 2 Ohio St. J. Crim. L. 579; M. Moore, "Choice, Character, and Excuse" (1990) 7 Social Philosophy and Policy 28; J. Hall, "Negligent Behaviour Should be Excluded from Criminal Liability" (1963) 63 Col. L.R. 632; J.W.C. Turner, "The Mental Element of Crimes at Common Law" in L. Radzinowicz and J.W.C. Turner (eds.) The Modern Approach to Criminal Law (London 1948) 195.

${ }^{51}$ See, e.g., A.P. Simester, Can Negligence be Culpable?" in J. Horder (ed.), Oxford Essays in Jurisprudence (4th Series, Oxford 2000) 85.

52 We are very grateful indeed for the penetrating comments and suggestions of Bob Sullivan on an earlier draft. Research for the essay was supported by a Singapore MoE Tier One Research Grant (R241000045112). 